
services"”

\title{
Avoiding paradigm drifts in IPBES: reconciling "nature's contributions to people," biodiversity, and ecosystem services
}

\author{
Daniel P. Faith ${ }^{1}$
}

Key Words: biodiversity; ecosystem services; IPBES; maintenance of options; nature's contributions to people; option value

\section{INTRODUCTION}

Peterson et al. (2018a) provided constructive commentary on the Díaz et al. (2018a) presentation of "nature's contributions to people" (NCP). Their discussion also built nicely on the other recent commentaries that discussed the similarities and differences of NCP and ecosystem services (ES), and the implications, not only for Intergovernmental Science-Policy Platform on Biodiversity and Ecosystem Services (IPBES), but also broader science and policy (e.g., Braat 2018, De Groot et al. 2018, Díaz et al. 2018b,c, Faith 2018a, Peterson et al. 2018b). It is not surprising that NCP has prompted all these discussions; the NCP framing may well influence the way we look at both the "B" and the "ES" in IPBES. As Díaz et al. (2018a) noted, NCP is an evolving framework. Its impact on IPBES assessments is not yet fully clear, noting that it was introduced after completion of some of the assessments, and in midstream for others (the regional assessments). Nevertheless, although the timing may not have been perfect, it seems clear that NCP is prompting worthwhile exploration of some issues that have been brewing for some time. Here, I will build directly on the useful discussion by Peterson et al. (2018a), to highlight some of the key issues for both the "B" and the "ES" in IPBES.

Díaz et al. (2018a:272) associated NCP with a "paradigm shift" in adding aspects of nature-people relationships that are missing from ES. Díaz et al. argued that the "NCP concept extends beyond the highly influential yet often contested notion of ecosystem services," noting that, historically, "the ecosystem services research program proceeded largely without benefiting from insights and tools in social sciences and humanities." Díaz et al. (2018b) summarized this key argument: "Substantial innovation in the NCP approach comes from incorporating the social sciences and humanities (SSH) much more centrally."

In response, others have argued that there is no real difference between NCP and ES. De Groot et al. (2018) characterized NCP and ES as "synonyms" (see also Costanza et al. 2017), and warned that "a hurried and top-down introduction of NCP as if it were a 'new' term risks plunging the large and diverse ES/NCP community into unnecessary paralysing debates..." Braat (2018: A1), writing as Editor-in-Chief of the journal Ecosystem Services, noted the history of ES papers already covering social sciences and other topics, and argued the following:

The authors of the Science paper have either missed all those developments...or have consciously chosen to ignore them, which raises questions about their intentions, and about the quality of IPBES publications to come.

Thus, Braat expressed concern about neglected history, and indeed about the possible adoption of a misleading, or even false, history (I return to this below, in evaluating the ES movement's own argumentations). Here, I highlight this issue, in part, because my own brief commentary (Faith 2018a) discussed the problem of neglected history, and its contribution to "paradigm drifts." As an example, I noted how both NCP and ES argumentation, in different ways, has misrepresented key messages from the Millennium Ecosystem Assessment (MA). My argument was that such paradigm drifts may prop up an alternative story line, or even a supposed "paradigm shift."

My other motivation for highlighting "paradigm drifts" in that commentary was to examine how biodiversity may be treated in $\mathrm{NCP}$, as compared to ES, framings. I referred to the early history of writings (going back roughly 50 years) about the value of biotic diversity (see review by Faith 2017). Historically, the loss of biotic diversity itself became a concern because this loss of living variation was interpreted as a loss of options for future generations (e.g., Ehrenfeld 1970, Iltis 1972, Haskins 1974, Roush 1977, see also historical reviews by Mazur and Lee 1993, Farnham 2007). My commentary described a biodiversity paradigm drift, where not only this basic history, but also the fundamental importance of these global "option values," have been neglected.

It is apparent, in all these discussions of NCP/ES "paradigm rifts," that history matters. Díaz et al. argued that cultural gaps exist that were foreshowed in work over the past decade; Braat noted years of ES papers that seemed to already cover what was claimed by Díaz et al. as innovative and new; Faith's "paradigm drifts" theme suggested that sometimes progress may be made more by considering what is old (and maybe neglected) than what is supposedly new.

\section{PETERSON ET AL. ON NCP AND ES}

The commentary by Peterson et al. (2018a) draws on the history of ES studies, in arguing that there is a significant "shortfall" in the NCP framing:

By replacing the term "ecosystems" with "nature," we argue that the nature's contributions to people approach underemphasizes the extent to which social-ecological processes are shaping the world's ecosystems. 
Peterson et al. highlighted, as a contrast, the history of ES work on human-transformed ecosystems, and they noted that "neither urban nor agro-ecosystems are typically considered or classified as "nature"" (see also Peterson et al. 2018b). Here, some recent history immediately is relevant. Díaz et al. (2018a) was not the first exposition of NCP; earlier IPBES papers that specifically focused on NCP include IPBES (2017) and Pascual et al. (2017). IPBES (2017:3) presented the rationale for NCP, and importantly noted:

IPBES considers all contributions of nature to the quality of life of humans as NCP, irrespective of how much human input is embedded in them through coproduction.

This appears to effectively counter the NCP shortfall claimed by Peterson et al. Thus, while Peterson et al. usefully highlighted the potential contributions from social-ecological processes shaping the world's ecosystems, there does not seem to be an immediate distinction to be made between ES and NCP in this context.

Recent history also helps to reveal another misrepresentation by Peterson et al. (2018a). This relates to biodiversity, and to the NCP category called "maintenance of options" (IPBES 2017, Díaz et al. 2018a). Peterson et al. argued the following:

Another major advance of the Díaz et al. (2018a) paper is related to the notion of the "maintenance of options" type of nature's contributions to people (NCP 18; Díaz et al. 2018a), enhancing "the capacity of ecosystems to keep options open in order to support a good quality of life" (Díaz et al. 2018a:SM). [Emphasis added]

It is good to see this enthusiasm for the "maintenance of options" NCP, which has been linked to biodiversity option values (Faith et al. 2017, Faith 2018a; Davies et al., in press). However, Peterson et al. here make a revealing misquotation. Díaz et al. (2018a:Table $\mathrm{S} 1$ ), in that Supplementary Material (SM), in fact describe "maintenance of options" as the "Capacity of ecosystems, habitats, species or genotypes to keep options open in order to support a good quality of life." [Italics added]

Misquotes are always a disservice to the reader, but this misrepresentation by Peterson et al. is particularly unfortunate because it gives the impression that the maintenance of options NCP is only about how ecosystems support human-well-being. In accord with this narrow perspective, Peterson et al. go on to endorse this maintenance of options NCP because it "represents a welcome place for cross-fertilization between the ecosystem services related research and the fields of resilience, adaptive capacity, transformation, and vulnerability." That accords nicely with ecosystem services work already progressing in that context, but it misses the point about how this NCP links to global option values of biodiversity (and its roughly 50-year-old history, referred to above). Indeed, the words excised by Peterson et al. from the IPBES definition (Díaz et al. 2018a, see also IPBES 2017) are exactly those that make the link to the various components of biodiversity that provide global biodiversity option value (for related discussion, see Faith 2003, 2017).

An interpretation of the maintenance of options NCP, as only about how ecosystems support human-well-being, can make a critical difference in the IPBES assessments. To illustrate this, we can compare a chapter from the IPBES "Methodological assessment of scenarios and models of biodiversity and ecosystem services" (IPBES 2016), which addressed nature's benefits but preceded NCP, to a chapter on nature's benefits (Davies et al., in press) from the IPBES Asia-Pacific regional assessment, which addressed the NCP framework.

Within the IPBES scenarios and models assessment, Peterson coled Chapter 5, "Modelling consequences of change in biodiversity and ecosystems for nature's benefits to people" (Peterson et al. 2016). As indicated in the introductory chapter to that overall assessment (Ferrier et al. 2016), Chapter 5 could be expected to include the following:

\section{Models addressing the consequences of changes in nature for the benefits that people derive from nature, and that therefore contribute to good quality of life (human well- being) - including, but not limited to, ecosystem goods and services (Ferrier et al. 2016:11).}

Logically, this would include direct benefits from biodiversity, including an historically fundamental benefit: biodiversity option values. Yet, in Chapter 5, this was never addressed. Instead, Chapter 5 set out to describe "the current state of ecosystem service models" (Peterson et al. 2016:201) and the chapter's background focused on benefits from ecosystems: "Demand for ecosystem services is increasing even as the intensified human modification of Earth's ecosystems is reducing the capacity of these ecosystems to continuously provide these benefits" (p. 205). Discussion of models incorporating biodiversity was only in the context of functions: e.g., in referring to: "Models of biodiversity and models of ecosystem services are not well connected. Ecologists increasingly understand how biodiversity produces ecological functions“" (p. 202).

Now, compare that to a recent IPBES assessment under the NCP framing. Chapter 2 of the Asia Pacific regional assessment (Davies et al., in press) addresses NCP, including maintenance of options. The assessment addressed biodiversity option value as one important aspect of maintenance of options, by adopting the biodiversity measure, "phylogenetic diversity" as an established proxy for option value (for background discussion, see Faith 2017). This Asia Pacific assessment chapter examined the status and trends globally for six major taxonomic groups, by looking at expected phylogenetic diversity losses. Thus, this regional-toglobal perspective on nature's contributions to people did not consider ecosystems, but it did focus on other biodiversity components, including species and genetic (phylogenetic) aspects.

The Peterson et al. (2018a) commentary expressed concern about "replacing the term "ecosystems" with "nature." That concern appears unwarranted, for two reasons: first, reference to NCP does not imply a neglect of human-transformed ecosystems, and second, and more importantly, it is exactly the reference to "nature," and not just "ecosystems," that promotes the consideration of global option values of biodiversity, as a key contribution of nature to people (see also Faith 1997, 2003, 2017).

\section{ECOSYSTEM SERVICES ARGUMENTATION}

The Peterson et al. (2018a) commentary seems to have echoed the perspectives from the scenarios and models chapter (Peterson et al. 2016), in focusing on benefits from ecosystem services. I think 
that this narrow perspective illustrates a more wide-spread problem. This may be understood by placing the commentary in the broader history of ES argumentations. For example, note that Peterson et al. (2016:204) justified their focus on "ecosystem services" in this way: "Nature provides multiple benefits to human societies. Throughout this chapter, these benefits are referred to as ecosystem services (MA, 2005b)."

I noted earlier how ES argumentation sometimes has misrepresented key messages from the Millennium Ecosystem Assessment (MA); this reference by Peterson et al. to the MA similarly is misleading. Importantly, the MA did not limit the multiple benefits of nature to "ecosystem services." In referring to benefits, the MA distinguished between ecosystem services and biodiversity option values. For example, the MA's "Biodiversity Synthesis" (MA 2005:7) concluded the following:

Conservation of biodiversity is essential as a source of particular biological resources, to maintain different ecosystem services, to maintain the resilience of ecosystems, and to provide options for the future.

Faith (2018a; see also Faith 2017) noted occasions where the MA has been recast as focused on ecosystem services from ecological production functions. Here, "biodiversity" is interpreted as supporting ecological functions. Thus, the narrow interpretation of the MA in the Peterson et al. (2016) chapter echoes other ES writings.

I think that this example illustrates a more general, recurrent, problem. One way to assess this is to return to the concerns about neglected, and false, history (see above) that were raised by Braat (2018) in his critique of NCP, and to apply these same standards to ES itself. I divide this discussion into two closely related aspects of ES argumentation:

1. Neglecting the history of biodiversity option value in the common statements that biodiversity value is based (only) on ecological functions, and;

2. Erecting a false history that ES developed as way to improve the case for biodiversity conservation, with ES work expanding the appreciation of biodiversity value beyond intrinsic value, to include anthropocentric values for the first time.

Neglect

The first point can be illustrated well by looking at two encyclopedia entries:

The Encyclopedia of Biodiversity has a whole chapter dedicated to "The Value of Biodiversity" (Dasgupta et al. 2013:168). This chapter states the following:

The value of biodiversity derives from the value of the final goods and services it produces. To estimate this value, one needs to understand the "production functions" that link biodiversity, ecosystem functions, ecosystem services, and the goods and services that enter into final demand.

Thus, the value of biodiversity here is tied only to ecological "production functions." Similarly, in the Encyclopedia of Biodiversity chapter on "Sustainability and Biodiversity"
(Cavender-Bares et al. 2013:73), the value of biodiversity is constrained in the same way:

A major challenge for the integration of biodiversity
conservation and providing for human well-being through
the framework of sustainability is the appropriate
valuation of biodiversity. This challenge begins with
determining the relationships between biodiversity and
ecosystem function, and between ecosystem functions
and their value of in terms of well-being, relationships
which are incompletely understood.

These narrow characterizations extend to other, recent, argumentation about biodiversity value. For example, Seddon et al. (2016:7) defined "biodiversity services" purely in terms of ecological processes:

Biodiversity is structured by a range of ecological processes .... These processes - which can be termed 'biodiversity services'-underpin and determine the stability, resilience, magnitude and efficiency of the functions and properties of ecosystems.

Faith (2018b) contrasted that narrow definition of "biodiversity services" with the previous use of the same term to include biodiversity option values. More importantly, this narrow definition adds to the other narrow characterizations of biodiversity value, noted above, that neglect previous history of thinking on biodiversity value that goes back some 50 years.

False history

Early history will not be discovered if history is rewritten. The neglect of biodiversity option value sometimes has been supported by a false history. In this story line, biodiversity historically had been recognized only as having intrinsic value, until ES provided it with anthropocentric values for the first time (a false history discussed in Faith 2012, 2017).

Daily et al. (2011:5) summarized this story line:

Including the value of ecosystem services ... does not replace or undermine the intrinsic value of nature, nor the moral imperative to conserve it ..... If we can add how nature contributes to human wellbeing to the arguments for conservation, why wouldn't we?

This has been a popular theme for ES workers. For example, Balvanera et al. (2001:2047) highlighted two principal approaches, one "focused on biodiversity conservation for its own sake, independent of human needs or desires" and the other "focused on safeguarding ecosystem services for humanity's sake." Reyers et al. (2012:503) similarly stated that "despite appeals about the intrinsic value of nature" biodiversity conservation is struggling, and argued the following:

In response, some within the conservation community have attempted to broaden the base of support for biodiversity conservation by adopting the concept of ecosystem services and by arguing that the conservation of biodiversity matters not only because of its intrinsic value but because it is essential for human well-being (Reyers et al. 2012:503).

This idea that ES set out to broaden the recognized value of biodiversity, beyond intrinsic value, appears to now be established 
as a cornerstone of ES history. For example, consider what is perhaps the most-cited history of ecosystem services: GómezBaggethun et al. (2010). This historical account presents the original motivation for considering ecosystem services as focused on biodiversity conservation:

It starts with the utilitarian framing of beneficial ecosystem functions as services in order to increase public interest in biodiversity conservation (Westman, 1977... (Gómez-Baggethun et al. 2010:1209).

In reality, Westman (1977) did not refer to biodiversity (nor "biotic diversity"). Westman linked functions instead to various aspects of ecology, including "how components of the system interact" (p. 961) and "the flow of materials and energy" (p. 963).

The inaugural paper in the journal, Ecosystem Services (Braat and de Groot 2012), basically repeat this same quote from GómezBaggethun et al. (2010), reinforcing the story-line that ES work was motivated by biodiversity conservation needs, and provided biodiversity with anthropocentric value for the first time.

I conclude this section with a caveat. I have only referred here to a small sample from the history of writings on biodiversity value and on ES (some additional historical perspective is provided in Faith 1997, 2003, 2017). But perhaps this sample is enough to warn us of a possible paradigm drift and its consequences. Peterson et al. (2018a) perhaps did not intend it, but, in fact, strengthened the case for why we need to move beyond standard ES framing. Peterson et al.'s use of a misquote, referring only to "ecosystems" as keeping options open, helps make the case why "replacing the term "ecosystems" with "nature,"” may be a good idea.

\section{BIS IPSUM IPBES EST?}

This tongue-in-cheek Latin title asks, twice-over, what "IPBES" itself means, given that both the "B" (biodiversity) and the "ES" (ecosystem services) parts may not yet have clear meanings in IPBES. I have described briefly the biodiversity paradigm drift associated with ES, but the status of "biodiversity" in IPBES assessments also now depends on its articulation within the NCP framing.

Faith (2018a) suggested that the "maintenance of options" NCP could help "repair" the biodiversity paradigm drift, but Faith also was troubled that the term "biodiversity" was not used in the description of that NCP (for useful discussion, see also Díaz et al. 2018c). In fact, in the earlier IPBES NCP papers (IPBES 2017, Pascual et al. 2017), the term "biodiversity" also hardly appeared anywhere in the texts.

This may reflect uncertainty that persists in the working definition of "biodiversity" in IPBES. Faith (2017) reviewed how definitions of biodiversity, under the ES argumentation, often have referred to most any aspects of ecology that support ecosystem services (so, providing something of a self-fulfilling prophecy that ES will give value to biodiversity). This issue may have been a consideration in development of the IPBES conceptual framework (Díaz et al. 2015:12), where biodiversity was linked properly to the idea of living variation, but the definition also was expanded to include "changes in abundance and distribution over time and space within and among species, biological communities and ecosystems" (see Faith 2017 for discussion).
The NCP framing may help promote a reconciliation, adding meaning to Peterson et al.'s (2018a) title phrase "welcoming different perspectives in IPBES." The NCP category, "maintenance of options," is appropriately broad enough to not only reinforce the importance of biodiversity as variety (with option value, insurance value, etc.), but also reinforce the importance of various aspects of ecology, linked to integrity, resilience, etc., that provide maintenance of options within ecosystems. Appreciating the importance of the former underscores the long history of biodiversity itself as having recognized value. Appreciating the importance of the latter underscores the long history of integrity and resilience as having recognized value, without any requirement that all that be labelled as "biodiversity."

\section{Responses to this article can be read online at: http://www.ecologyandsociety.org/issues/responses. php/10195}

\section{Acknowledgments:}

I thank participants at IPBES-6 for helpful conversations on this topic. I thank the IPBES Coordinating Lead Authors from the AsiaPacific and the Europe and Central Asia regional assessments for their support for the communication of biodiversity option value.

\section{LITERATURE CITED}

Balvanera, P., G. C. Daily, P. R. Ehrlich, T. H. Ricketts, S.-A. Bailey, S. Kark, C. Kremen, and H. Pereira. 2001. Conserving biodiversity and ecosystem services. Science 291:2047. DOI: 10.1126/science.291.5511.2047 http://dx.doi.org/10.1126/ science.291.5511.2047

Braat, L. C. 2018. Five reasons why the Science publication "Assessing nature's contributions to people" (Díaz et al. 2018) would not have been accepted in Ecosystem Services. Ecosystem Services 30(Part A):A1-A2. http://dx.doi.org/10.1016/j.ecoser.2018.02.002

Braat, L. C., and R. De Groot. 2012. The ecosystem services agenda: bridging the worlds of natural science and economics, conservation and development, and public and private policy. Ecosystem Services 1:4-15. http://dx.doi.org/10.1016/j.ecoser.2012.07.011

Cavender-Bares, J., J. Heffernan, E. King, S. Polasky, P. Balvanera, and W. C. Clark. 2013. Sustainability and biodiversity. Pages 71-84 in S. A. Levin, editor. Encyclopedia of biodiversity. Second edition, Volume 7. Academic Press, Waltham, Massachusetts, USA. http://dx.doi.org/10.1016/B978-0-12-384719-5.00390-7

Costanza, R., R. de Groot, L. Braat, I. Kubiszewski, L. Fioramonti, P. Sutton, S. Farber, and M. Grasso. 2017. Twenty years of ecosystem services: How far have we come and how far do we still need to go? Ecosystem Services 28:1-16. http://dx.doi. org/10.1016/j.ecoser.2017.09.008

Daily, G. C., P. M. Kareiva, S. Polasky, T. H. Ricketts, and H. Tallis. 2011. Mainstreaming natural capital into decisions. Pages 3-14 in P. Kareiva, H. Tallis, T. H. Ricketts, G. C. Daily, and S. Polasky, editors. Natural capital: theory and practice of mapping 
ecosystem services. Oxford University Press, New York, New York, USA. http://dx.doi.org/10.1093/acprof:oso/978019958899$\underline{2.003 .0001}$

Dasgupta, P., A. P. Kinzig, and C. Perrings. 2013. The value of biodiversity. Pages 167-179 in S. A. Levin, editor. Encyclopedia of biodiversity. Second edition, Volume 7. Academic Press, Waltham, Massachusetts, USA. http://dx.doi.org/10.1016/B978-0-12-3847$\underline{19-5.00372-5}$

Davies, K., A. Rajvanshi, Y. Yeo-Chang, A. Gautam, A. Choi, A. Masoodi, C. Togtokh, H. Sandhu, H. Husain, J. Cho, et al. In press. Chapter 2 in M. Karki and S. Sonali, editors. Nature's contributions to people and quality of life. IPBES, 2018: Regional and subregional assessment of biodiversity and ecosystem services for Asia and the Pacific. Secretariat of the Intergovernmental Platform for Biodiversity and Ecosystem Services, Bonn, Germany.

De Groot, R., R. Costanza, L. Braat, L. Brander, B. Burkhard, L. Carrasco, N. Crossman, B. Egoh, D. Geneletti, B. Hansjuergens, L. Hein, S. Jacobs, I. Kubiszewski, B. Leimona, B. Li, J. Liu, S. Luque, J. Maes, C. Marais, S. Maynard, L. Montanarella, S. Moolenaar, C. Obst, M. Quintero, O. Saito, F. Santos-Martin, P. Sutton, P. van Beukering, M. van Weelden, and L. Willemen. 2018. RE: Ecosystem services are nature's contributions to people. Science E-Letter, 27 February. [online] URL: $\underline{\text { http://science.sciencemag.org/content/359/6373/270/tab-e- }}$ letters

Díaz, S., S. Demissew, J. Carabias, C. Joly, M. Lonsdale, N. Ash, A. Larigauderie, J. R. Adhikari, S. Arico, A. Báldi, A. Bartuska, I. A. Baste, A. Bilgin, E. Brondizio, K. M. A. Chan, V. E. Figueroa, A. Duraiappah, M. Fischer, R. Hill, T. Koetz, P. Leadley, P. Lyver, G. M. Mace, B. Martin-Lopez, M. Okumura, D. Pacheco, U. Pascual, E. S. Pérez, B. Reyers, E. Roth, O. Saito, R. J. Scholes, N. Sharma, H. Tallis, R. Thaman, R. Watson, T. Yahara, Z. A. Hamid, C. Akosim, Y. Al-Hafedh, R. Allahverdiyev, E. Amankwah, T. S. Asah, Z. Asfaw, G. Bartus, A. L. Brooks, J. Caillaux, G. Dalle, D. Darnaedi, A. Driver, G. Erpul, P. EscobarEyzaguirre, P. Failler, A. M. M. Fouda, B. Fu, H. Gundimeda, S. Hashimoto, F. Homer, S. Lavorel, G. Lichtenstein, W. A. Mala, W. Mandivenyi, P. Matczak, C. Mbizvo, M. Mehrdadi, J. P. Metzger, J. B. Mikissa, H. Moller, H. A. Mooney, P. Mumby, H. Nagendra, C. Nesshover, A. A. Oteng-Yeboah, G. Pataki, M. Roué, J. Rubis, M. Schultz, P. Smith, R. Sumaila, K. Takeuchi, S. Thomas, M. Verma, Y. Yeo-Chang, and D. Zlatanova. 2015. The IPBES conceptual framework - connecting nature and people. Current Opinion in Environmental Sustainability 14:1-16. http:// dx.doi.org/10.1016/j.cosust.2014.11.002

Díaz, S., U. Pascual, M. Stenseke, B. Martín-López, R. T. Watson, Z. Molnár, R. Hill, K. M. A. Chan, I. A. Baste, K. A. Brauman, S. Polasky, A. Church, M. Lonsdale, A. Larigauderie, P. W. Leadley, A. P. E. van Oudenhoven, F. van der Plaat, M. Schröter, S. Lavorel, Y. Aumeeruddy-Thomas, E. Bukvareva, K. Davies, S. Demissew, G. Erpul, P. Failler, C. A. Guerra, C. L. Hewitt, H. Keune, S. Lindley, and Y. Shirayama. 2018a. Assessing nature's contributions to people. Science 359(6373):270-272. http://dx.doi. org/10.1126/science.aap8826

Díaz, S., U. Pascual, M. Stenseke, B. Martín-López, R. T. Watson, Z. Molnár, R. Hill, K. M. A. Chan, I. A. Baste, K. A. Brauman,
S. Polasky, A. Church, M. Lonsdale, A. Larigauderie, P. W. Leadley, A. P. E. van Oudenhoven, F. van der Plaat, M. Schröter, S. Lavorel, Y. Aumeeruddy-Thomas, E. Bukvareva, K. Davies, S. Demissew, G. Erpul, P. Failler, C. A. Guerra, C. L. Hewitt, H. Keune, S. Lindley, and Y. Shirayama. 2018b. RE: There is more to nature's contributions to people than ecosystem services - a response to de Groot et al. Science E-Letter, 12 March. [online] URL: http://science.sciencemag.org/content/359/6373/270/tab-e$\underline{\text { letters }}$

Díaz, S., U. Pascual, M. Stenseke, B. Martín-López, R. T. Watson, Z. Molnár, R. Hill, K. M. A. Chan, I. A. Baste, K. A. Brauman, S. Polasky, A. Church, M. Lonsdale, A. Larigauderie, P. W. Leadley, A. P. E. van Oudenhoven, F. van der Plaat, M. Schröter, S. Lavorel, Y. Aumeeruddy-Thomas, E. Bukvareva, K. Davies, S. Demissew, G. Erpul, P. Failler, C. A. Guerra, C. L. Hewitt, H. Keune, S. Lindley, and Y. Shirayama. 2018c. RE: Shifts, drifts and options- A response to Faith. Science E-Letter, 16 February. [online] URL: http://science.sciencemag.org/content/359/6373/270/ tab-e-letters

Ehrenfeld, D. W. 1970. Biological conservation. Holt Rinehart and Winston, New York, New York, USA.

Faith, D. P. 1997. Biodiversity, biospecifics and ecological services. Trends in Ecology and Evolution 12:66. http://dx.doi.org/10.1016/ $\underline{\mathrm{S} 0169-5347(97) 82677-8}$

Faith, D. P. 2003. Biodiversity. In Stanford encyclopedia of philosophy. Summer 2003 edition. E. N. Zalta, editor. The Metaphysics Research Lab, Center for the Study of Language and Information, Stanford University, Stanford, California, USA. [online] URL: https://plato.stanford.edu/archives/sum2016/entries/ biodiversity/

Faith, D. P. 2012. Common ground for biodiversity and ecosystem services: the "partial protection" challenge. F1000 Research 1:30 http://dx.doi.org/10.12688/f1000research.1-30.v1

Faith, D. P. 2017. A general model for biodiversity and its value. Pages 69-85 in J. Garson, A. Plutynski, and S. Sarkar, editors. The Routledge Handbook of Philosophy of Biodiversity Routledge, London, UK.

Faith, D. P. 2018a. IPBES and paradigm drifts. Science E-Letter, 14 February. http://science.sciencemag.org/content/359/6373/270/ tab-e-letters

Faith, D. P. 2018b. How we should value biodiversity in the Anthropocene. Proceedings of the Royal Society B, Biological Sciences 283. [online] URL: http://rspb.royalsocietypublishing. org/content/how-we-should-value-biodiversity-anthropocene

Faith, D. P., S. Magallón, A. P. Hendry, and M. J. Donoghue. 2017. Future benefits from contemporary evosystem services: a response to Rudman et al. Trends in Ecology and Evolution 32:717-719. http://dx.doi.org/10.1016/j.tree.2017.07.005

Farnham, T. J. 2007. Saving nature's legacy: origins of the idea of biological diversity. Yale University Press, New Haven, Connecticut, USA.

Ferrier, S., K. N. Ninan, P. Leadley, R. Alkemade, G. Kolomytsev , M. Moraes, E.Y. Mohammed, and Y. Trisurat. 2016. Overview and vision. Pages 1-33 in S. Ferrier, K. N. Ninan, P. Leadley, R. 
Alkemade, L. A. Acosta, H. R. Akçakaya, L. Brotons, W. W. L. Cheung, V. Christensen, K. A. Harhash, J. Kabubo-Mariara, C. Lundquist, M. Obersteiner, H. Pereira, G. Peterson, R. PichsMadruga, N. Ravindranath, C. Rondinini, and B. A. Wintle, editors. The methodological assessment report on scenarios and models of biodiversity and ecosystem services. Secretariat of the Intergovernmental Platform for Biodiversity and Ecosystem Services, Bonn, Germany.

Gómez-Baggethun, E., R. de Groot, P. L. Lomas, and C. Montes. 2010. The history of ecosystem services in economic theory and practice: from early notions to markets and payment schemes. Ecological Economics 69:1209-1218. http://dx.doi.org/10.1016/j. ecolecon.2009.11.007

Haskins, C. 1974. Scientists talk of the need for conservation and an ethic of biotic diversity to slow species extinction. Science 184:646-647. http://dx.doi.org/10.1126/science.184.4137.646

Iltis, H. H. 1972. Shepherds leading sheep to slaughter: the extinction of species and the destruction of ecosystems. American Biology Teacher 34:201-221. http://dx.doi.org/10.2307/4443886

Intergovernmental Platform for Biodiversity and Ecosystem Services (IPBES). 2016. The methodological assessment report on scenarios and models of biodiversity and ecosystem services. $\mathrm{S}$. Ferrier, K. N. Ninan, P. Leadley, R. Alkemade, L. A. Acosta, H. R. Akçakaya, L. Brotons, W. W. L. Cheung, V. Christensen, K. A. Harhash, J. Kabubo-Mariara, C. Lundquist, M. Obersteiner, H. Pereira, G. Peterson, R. Pichs-Madruga, N. Ravindranath, C. Rondinini, and B. A. Wintle, editors. Secretariat of the Intergovernmental Platform for Biodiversity and Ecosystem Services, Bonn, Germany.

Intergovernmental Platform for Biodiversity and Ecosystem Services (IPBES). 2017. Update on the classification of nature's contributions to people by the Intergovernmental Science-Policy Platform on Biodiversity and Ecosystem Services. IPBES/5/ INF/24. Plenary of the Intergovernmental Science-Policy Platform on Biodiversity and Ecosystem Services, Fifth session, Bonn, Germany.

Mazur, A., and J. Lee. 1993. Sounding the global alarm: environmental issues in the US national news. Social Studies of Science 23:681-720. http://dx.doi.org/10.1177/030631293023004003

Millennium Ecosystem Assessment. 2005. Ecosystems and human well-being: biodiversity synthesis. World Resources Institute, Washington, D.C., USA.

Pascual, U., P. Balvanera, S. Díaz, G. Pataki, E. Roth, M. Stenseke, R. T. Watson, E. B. Dessane, M. Islar, E. Kelemen, et al. 2017. Valuing nature's contributions to people: the IPBES approach. Current Opinion in Environmental Sustainability 26-27:7-16. http://dx.doi.org/10.1016/j.cosust.2016.12.006

Peterson, G. D., Z. V. Harmackova, M. Meacham, C. Queiroz, A. J. Aceituno, J. J. Kuiper, K. Malmborg, N. E. Sitas, and E. M. Bennett. 2018a. Welcoming different perspectives in IPBES: "Nature's contributions to people" and "Ecosystem services." Ecology and Society 23(1):39. http://dx.doi.org/10.5751/ ES-10134-230139

Peterson, G. D., Z. V. Harmackova, M. Meacham, C. Queiroz, A. J. Aceituno, J. J. Kuiper, K. Malmborg, N. E. Sitas, and E. M.
Bennett. 2018b. Connecting people's contributions to nature to nature's contributions to people. Science E-Letter, 18 March. http://science.sciencemag.org/content/359/6373/270/tab-e-letters

Peterson, G., J. Kabubo-Mariara, N. Crossman, B. Rashleigh, P. Munoz, J. Anticamara, M. V. Mdemu and A. Aunins. 2016. Modelling consequences of change in biodiversity and ecosystems for nature's benefits to people. Pages 199-243 in S. Ferrier, K. N. Ninan, P. Leadley, R. Alkemade, L. A. Acosta, H. R. Akçakaya, L. Brotons, W. W. L. Cheung, V. Christensen, K. A. Harhash, J. Kabubo-Mariara, C. Lundquist, M. Obersteiner, H. Pereira, G. Peterson, R. Pichs-Madruga, N. Ravindranath, C. Rondinini, and B. A. Wintle, editors. The methodological assessment report on scenarios and models of biodiversity and ecosystem services. Secretariat of the Intergovernmental Platform for Biodiversity and Ecosystem Services, Bonn, Germany.

Reyers, B., S. Polasky, H. Tallis, H. A. Mooney, and A. Larigauderie. 2012. Finding a common ground for biodiversity and ecosystem services. Bioscience 62:503-507. http://dx.doi. org/10.1525/bio.2012.62.5.12

Roush, G. 1977. Why save diversity? Nature Conservancy News 21:9-12.

Seddon, N., G. M. Mace, S. Naeem, J. A. Tobias, A. L. Pigot, R. Cavanagh, D. Mouillot, J. Vause, and M. Walpole. 2016. Biodiversity in the Anthropocene: prospects and policy. Proceedings of the Royal Society B, Biological Sciences 283:20162094. http://dx.doi.org/10.1098/rspb.2016.2094 http:// dx.doi.org/10.1098/rspb.2016.2094

Westman, W. E. 1977. How much are nature's services worth? Science 197:960-964. http://dx.doi.org/10.1126/science.197.4307.960 